\title{
DNA detection of Helicobacter pylori in saliva of patients with low salivary $\mathrm{pH}$
}

\section{Abstract}

Background and objective: One of the well-organized diagnostic methods of Helicobacter pylori (H. pylori) infection is bacterial DNA detection in saliva using polymerase chain reaction (PCR). However, a wide range of factors is present in human saliva that could hinder detection efficiency. One of these factors seems to be the $\mathrm{pH}$ of saliva, which is investigated in this study as to whether its variation could have any effects on $H$. pylori DNA presence in the saliva of infected patients.

Methods: Saliva samples of $89 \mathrm{H}$. pylori-infected Patients were collected and measured for $\mathrm{pH}$ levels. The DNA of $H$. pylori was extracted from the saliva of patients and then quantified directly by Real-time PCR. One Way ANOVA and Linear Regression tests were performed to determine the effect of $\mathrm{pH}$ on the detection of $H$. pylori DNA in the saliva.

Results: $58 \%$ of samples were PCR positive (17\% high, $19 \%$ medium, and $22 \%$ low titer), and no DNA was detected in $42 \%$ samples. There was no significant association between the age of patients and the detection of DNA $(P=0.98)$. A statistically significant difference in $\mathrm{pH}$ level was found between negative and positive PCR samples. Calculation of linear regression of DNA copy numbers and independently increasing $\mathrm{pH}$ showed $\mathrm{R}^{2}=0.041$.

Conclusion: The ability to detect $H$. Pylori DNA was generally confined to $\mathrm{pH}$ of 5.5 to 7.5 with an apparently reduced detectability at above neutral $\mathrm{pH}$ of saliva. However, $\mathrm{pH}$ variation from 5.5 to 7.5 did not determine the levels of detected DNA of $H$. pylori in saliva.

Keywords: H. pylori; Gastric ulcer; Real-Time PCR; Saliva; Salivary pH.

\section{Introduction}

$H$. pylori are gram-negative spiral bacteria that reside in the gastrointestinal tract of human. They have a narrow host range and habitually establish a lifelong infection suggesting a robust adaptation to its habitat. The bacteria lack a number of biosynthetic pathways for several amino acids, which make limited in vitro growth. ${ }^{1}$ They are responsible for gastric ulcer and a well-recognized risk factor for gastric cancer. $^{2}$ In this regard, gastric cancer is considered as the third leading cancerrelated cause of death globally, with $H$. pylori infection being responsible for nearly $75 \%$ of all non-cardia gastric cancer cases. ${ }^{3,4}$ Annually, million deaths worldwide occur due to gastric and peptic cancers making it a globally important health issue. ${ }^{5}$ In view of the fact that the main route of transmission of $H$. pylori is fecal-oral, the higher levels of infection are associated with low levels of sanitation and socioeconomic status. ${ }^{6}$ A number of studies have demonstrated the association of gastroesophageal infections with the presence of $H$. pylori in the oral cavity. ${ }^{7,8}$ Thus, failure to eradicate $H$. pylori from the oral cavity might result in gastrointestinal reinfection. ${ }^{9,10}$ Despite the eradication of $H$. pylori from the stomach, early reinfection of the stomach can be promoted due to the survival of bacteria in the oral cavity. Such a function of the oral cavity in serving as

${ }^{1}$ Department of Basic Sciences, College of Medicine, Hawler Medical University, Erbil, Iraq.

2 Department of Oral Medicine, College of Dentistry, Hawler Medical University, Erbil, Iraq.

${ }^{3}$ Department of Orthodontics, College of Dentistry, Hawler Medical University, Erbil, Iraq.

* Correspondence: amin.bakir@hmu.edu.krd 
a sanctuary for $H$. pylori could reduce the efficacy of eradication therapy. ${ }^{11}$ Poor salivary secretion can possibly lead to the dental plaque deposition which can also provide a favorable environment for the growth of bacteria such as $H$. pylori. ${ }^{12}$ Several types of salivary glands secrete saliva, each with different compositions and properties. Accordingly, the secretions from various glands considerably differ in composition and are affected by different stimuli, diet, time of day, age, gender, health status, and various pharmacological substances. Whole saliva is a clear, slightly acidic ( $\mathrm{pH} 6$ to 7), mixed fluid containing mucosal transudations, gingival crevicular fluid, expectorated nasal and bronchial secretions, desquamated epithelial cells, debris from food, bacterial products, viruses, and fungi ${ }^{13}$. Saliva has often been proposed as a diagnostic tool specifically promoted by the current technological advancement such as PCR, Western blotting assay and Enzyme-linked Immunosorbent Assay(ELISA). ${ }^{14}$ Various diagnostic tools have been developed to detect $H$. pylori, including invasive (e.g., endoscopic based) and non-invasive techniques. Among non-invasive diagnostic methods, the most commonly applied are stool antigen test, urea breath test, serological test, and molecular techniques. ${ }^{15}$ Saliva is often taken for molecular detection of $H$. pylori at the DNA level. ${ }^{16}$ In that sense, the salivary components could affect the survival of bacteria and, more pertinently, the integrity of DNA used for PCR. Moreover, the $\mathrm{pH}$ of saliva could implement its own impact on the presence of $H$. pylori in the oral cavity. One instant is likely to be the function of salivary nitrite on the killing of $H$. pylori. ${ }^{17}$ Thus, this study was performed with the aim to define the association of salivary $\mathrm{pH}$ with the presence of $H$. pylori DNA and further with the growth of $H$. pylori in saliva.

\section{Methods}

Study design

This prospective study was performed on
89 patients admitted to Rizgary Teaching Hospital, whose gastric biopsy showed positive growth for $H$. pylori. All work and protocols in this research were approved by the Ethics Committee in the College of Medicine at Hawler Medical University (Paper Code: 5 issued on 20-12-2018). The handling of the biological specimen was done according to the Declaration of Helsinki criteria. ${ }^{18}$ Samples of saliva were collected from June to November 2018 from Rizgary Teaching Hospital. The exclusion criteria were: antibiotics within the previous two weeks, age over 80 years, and severe concomitant diseases.

\section{Sample collection}

The patients were informed about the procedure, and information on gender and age was recorded (Table 1) before sampling. $5 \mathrm{~mL}$ saliva was collected and placed into a sterile polystyrene tube with the cap was firmly closed according to the previous work by Cellini et al. ${ }^{19}$ The specimens were immediately transferred within less than 2 hours at $10^{\circ} \mathrm{C}-15^{\circ} \mathrm{C}$ to Genome Diagnosis Lab (GDL).

\section{Saliva analysis}

The saliva samples were measured for their $\mathrm{pH}$ using Professional Benchtop $\mathrm{pH}$ meter BP3001 (Trans Instruments, Petro Centre, Singapore). DNA extraction was done using Bacterial DNA Preparation kit (Jena Bio Science, Thuringia, Germany). Briefly, saliva was vortexed for 10 seconds to get a homogenous suspension then $500 \mu \mathrm{L}$ was transferred into a $1.5 \mathrm{~mL}$ cap tube. After centrifugation at $1000 \mathrm{~g}$ for 1 minute, the supernatant was discarded, and the pellet was resuspended in $300 \mu \mathrm{L}$ Lysis Buffer, $2 \mu \mathrm{L}$ RNase $\mathrm{A}$, and $8 \mu \mathrm{L}$ of Proteinase $\mathrm{K}$ then incubated at $60^{\circ} \mathrm{C}$ for 10 minutes. The solution was then added to a spin column and washed twice with washing solution via centrifugation. DNA was recovered by adding $50 \mu \mathrm{L}$ DNase-RNase free water to the column and centrifuging for 2 minutes at $1000 \mathrm{~g}$. The DNA was measured for quantity and purity via Nanophotometer (IMPLEN, CA, USA). 
Real-Time PCR

Real-time PCR was performed to bacteria extractions by RealLine ${ }^{\mathrm{TM}}$ Helicobacter pylori Str-Format kit (VBD3798, BIORON, Ludwigshafen, Germany). Using Eco Real-Time PCR machine (Illumina, CA, USA) $50 \mu \mathrm{L}$ of the isolated DNA solution was added to the ready master mix tube. The tubes were placed into the Real-Time PCR system programmed as $50^{\circ} \mathrm{C}$ for 2 min initiation and $95^{\circ} \mathrm{C}$ for 2 min initiation. Then it was followed by 50 cycles of $94^{\circ} \mathrm{C}$ for 10 seconds and $60^{\circ} \mathrm{C}$ for 20 seconds. The fluorescence intensity was measured at $60^{\circ} \mathrm{C}$. FAM channel was set to detect Internal Control amplification, and ROX channel was set to collect $H$. pylori DNA amplification signals. Positive and negative controls were applied according to the kit's instruction manual. Relative quantification of DNA (semi-quantification) was performed by measuring the difference between $\mathrm{Ct}$ (cycle threshold) values of positive control and the tested sample using $2^{-\Delta \Delta \mathrm{Ct}}$ method. $^{20}$ The bacterial DNA load values were divided into three groups based on the mean concentrations (i.e., 45000 copies / mL) of positive control. In this regards, the relative concentrations less than 10000 copies / $\mathrm{mL}$ were assigned as "Low", from 10000 to 100000 copies $/ \mathrm{mL}$ were named as "Medium", and concentrations above 100000 copies / mL were regarded as "High".

\section{Data analysis}

The Data analysis was done by GraphPad Prism v6. A $P$ value of 0.05 was considered as statistically significant. Chi Square, Student t-test, and One Way ANOVA tests were applied to find out the statistically significant differences between studied groups.

\section{Results}

The patients' age was arranged as 10 years intervals with the number and percentage of each age group based on gender distribution (Table 1).

\section{Detection of $\boldsymbol{H}$. pylori DNA in relation to gender}

There were 52 detected $H$. pylori DNA samples, of which $32(61 \%)$ were male, and $20(38.46 \%)$ were female (Table 2$)$.

Table 1: Age and gender distribution of patients.

\begin{tabular}{lccc}
\hline Age (years) & $\begin{array}{c}\text { Female } \\
\text { No. (\%) }\end{array}$ & $\begin{array}{c}\text { Male } \\
\text { No. (\%) }\end{array}$ & $\begin{array}{c}\text { Total } \\
\text { No. (\%) }\end{array}$ \\
\hline $20-29$ & $12(31.57)$ & $18(35.29)$ & $30(33.70)$ \\
$30-39$ & $15(39.47)$ & $16(31.37)$ & $31(34.83)$ \\
$40-49$ & $9(23.68)$ & $13(25.49)$ & $22(24.72)$ \\
$\geq 50$ & $2(5.26)$ & $4(7.84)$ & $6(6.75)$ \\
Total & $\mathbf{3 8 ( 1 0 0 . 0 )}$ & $\mathbf{5 1 ( 1 0 0 . 0 )}$ & $\mathbf{8 9 ( 1 0 0 )}$ \\
\hline
\end{tabular}

Table 2: Detected and not detected DNA according to gender.

\begin{tabular}{lcccc}
\hline Gender & $\begin{array}{c}\text { Detected } \\
\text { No. (\%) }\end{array}$ & $\begin{array}{c}\text { Not Detected } \\
\text { No. (\%) }\end{array}$ & $\begin{array}{c}\text { Total } \\
\text { No. (\%) }\end{array}$ & P value \\
\hline Male & $32(62.7)$ & $19(37.3)$ & $51(100)$ & $\mathbf{0 . 3 3 8}$ \\
Female & $20(52.6)$ & $18(47.4)$ & $38(100)$ & \\
Total & $\mathbf{5 2 ( 5 8 . 4 )}$ & $\mathbf{3 7 ( 4 1 . 6 )}$ & $\mathbf{8 9 ( 1 0 0 )}$ & \\
\hline
\end{tabular}


Detection of $\mathrm{H}$. pylori DNA in relation to age

The associations of the age of patients with the presence of $H$. pylori DNA in their saliva samples were investigated. The efficiency of DNA detection was greater at the age of 20 to 40 years, and it was found to be equal at older ages. Chi-square test was applied to compare the age groups regarding their level of DNA detection (Figure 1A). Nevertheless, taking the overall effect of age into account, there was no statistically significant difference between detection and no detection of $H$. pylori DNA in saliva at different ages. The t-test of two independent samples was performed to compare the overall detection level in all ages (Figure 1B).

Measurement of detected $H$. pylori DNA $H$. pylori DNA in the saliva samples of patient was detected and quantified using Real-Time PCR method, as shown in Figure 2.

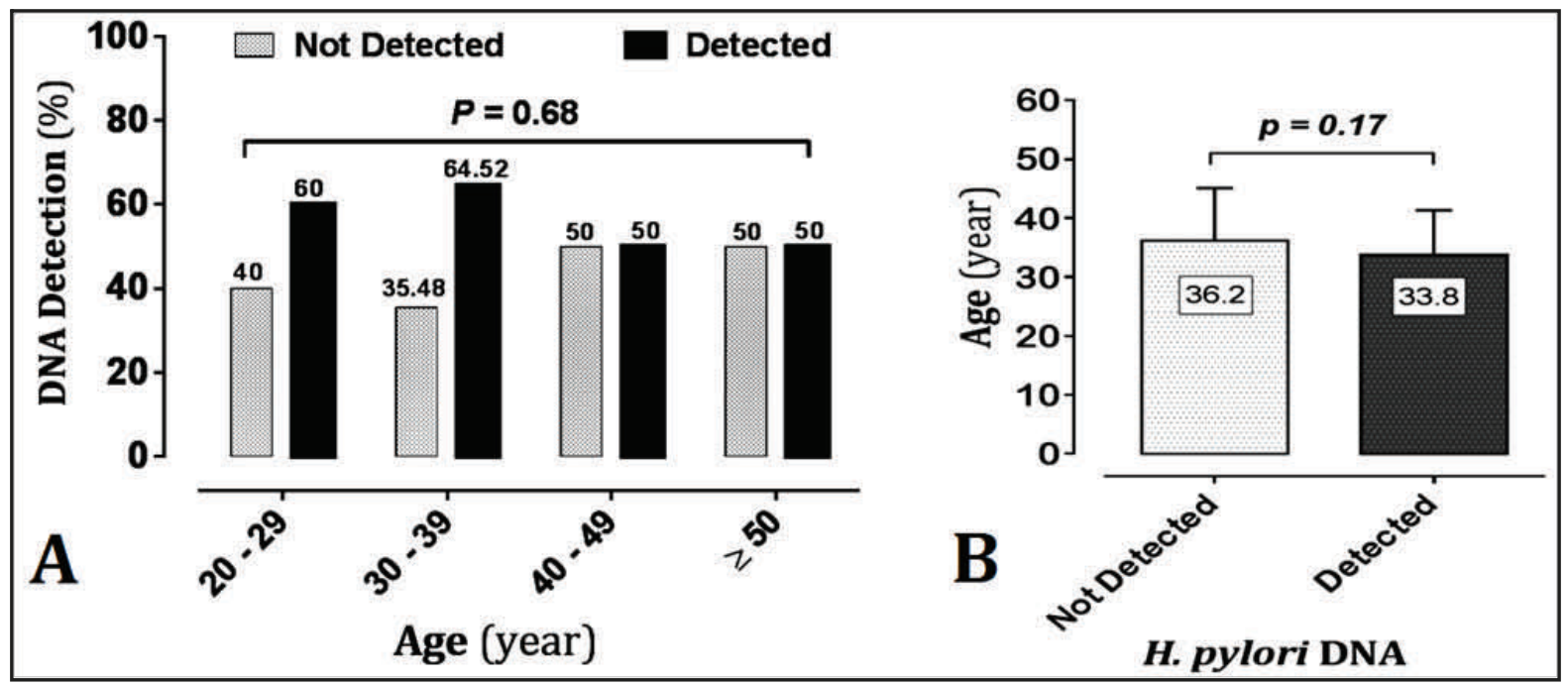

Figure 1: $H$. pylori DNA detection in the saliva is generally higher at younger ages. Error Bars $=$ Standard Deviation

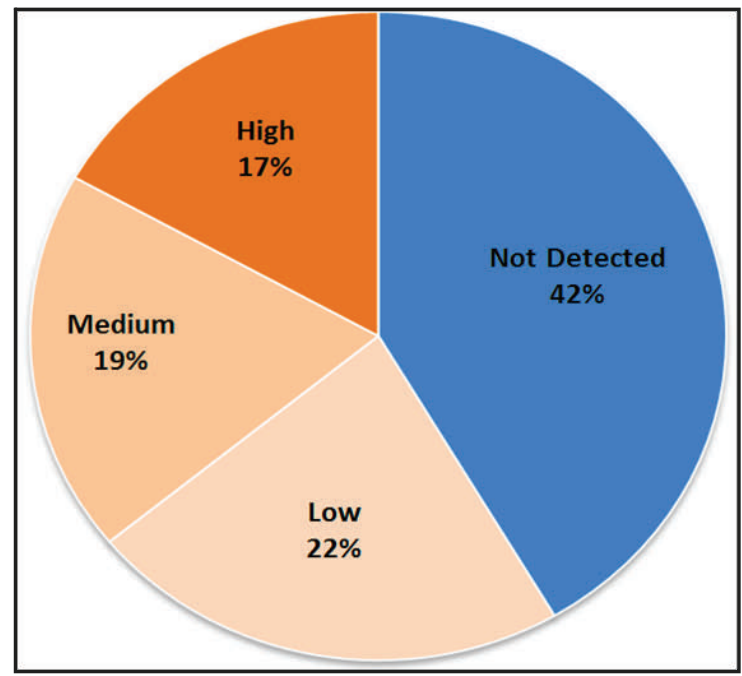

Figure 2: More than half of saliva samples were detected with $H$. pylori DNA. The samples with DNA detection were grouped into low, medium and high according to the quantification. 


\section{Association of bacterial DNA load with salivary $\mathrm{pH}$}

Detection of $H$. pylori DNA in the saliva and its association with the $\mathrm{pH}$ levels of saliva is shown in Table 3. A statistically significant difference was inferred among "High," "Medium," "Low," and "Not Detected" groups after ANOVA test. To explore further, the significant difference was only attributed to the "Not Detected" with other groups using Fisher's Least
Significant Difference test.

Association of bacterial DNA load with salivary $\mathrm{pH}$

The levels of $H$. pylori DNA copy number with increasing $\mathrm{pH}$ of saliva is shown in Figure 3. The relative concentration (copies / $\mathrm{mL}$ ) of $H$. pylori DNA in saliva of patients was plotted, and the linear regression of concentration as to the independently increasing $\mathrm{pH}$ levels was measured.

Table 3: Association of salivary $\mathrm{pH}$ with the level of DNA detection.

\begin{tabular}{lccc}
\hline DNA Detection & Mean & pH & ISD \\
\hline High & & 6.17 & 0.66 \\
Medium & & 6.30 & 0.62 \\
Low & & 6.54 & 0.80 \\
Not Detected & 7.14 & 1.02 \\
One Way ANOVA (P value) & & 0.0026 & \\
Least Significant Difference: & & & \\
Not Detected vs. High: & $\boldsymbol{P}<\mathbf{0 . 0 0 0 1}$ & \\
Not Detected vs. Medium: & $\boldsymbol{P}<\mathbf{0 . 0 0 0 1}$ & & \\
Not Detected vs. Low: & $\boldsymbol{P}<\mathbf{0 . 0 0 0 1}$ & & \\
High vs. Medium: & $\boldsymbol{P}=\mathbf{0 . 0 7 3 2}$ & & \\
High vs. Low: & $\boldsymbol{P}=\mathbf{0 . 6 8 3 8}$ & & \\
Medium vs. Low: & $\boldsymbol{P}=\mathbf{0 . 1 4 4 5}$ & & \\
\hline
\end{tabular}

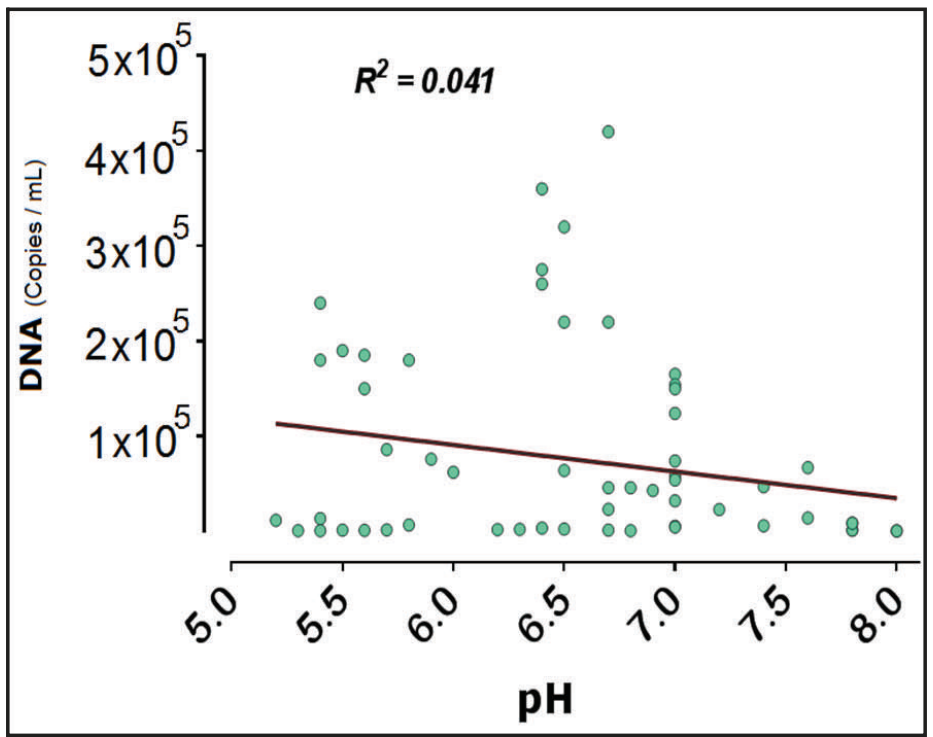

Figure 3: A scatter diagram of bacterial DNA load at increasing $\mathrm{pH}$ of saliva. $P$ value $=0.07$ and $r=-0.23$ Line: Best fit line from Linear Regression. 


\section{Discussion}

$H$. pylori has been co-evolved with humans since the beginning of human history, ${ }^{21}$ causing an infection that is considered one of the most prevalent chronic bacterial diseases worldwide. ${ }^{22}$ A number of survival strategies developed throughout this association to persist the challenging environments in the human body. Indeed, the survival of $H$. pylori relies on its ability to circumvent the antimicrobial effects of stomach acid. ${ }^{23}$ Nevertheless, the main reservoir of $H$. pylori, as suggested by the recent studies, is identified to be in the oral cavity. ${ }^{24}$ Studies propose oral spread of bacteria via saliva to be one of the primary modes of transmission. ${ }^{25}$ In this regard, detection of $H$. pylori DNA in saliva using PCR in this study appears to be an efficient way and to detect infection which has been applied by other studies. ${ }^{26-28}$ Although a meta-analysis of relevant studies imply that gastric infection with $H$. pylori doubles the likelihood of finding $H$. pylori in the oral cavity, ${ }^{29}$ it is also possible that the stomach colonization occurs independently of $H$. pylori detection in the mouth. ${ }^{19}$ There might be many elements potentially involved, including age and gender of the infected individual as well as components of saliva. In view of that, the scheme of data shows a higher incidence of salivary $H$. pylori DNA in males than females (Table 2). Nevertheless, our investigation to find the possible link between age and detection of $H$. pylori DNA (Figure 1) revealed no significant effect though the younger ages were found with slightly higher DNA detection levels (Figure 1A). Having considered the age, it is well known that human saliva has miscellaneous substances and a variety of anti-bacterial mechanisms. ${ }^{25}$ In an attempt to address the central concern of this study, relative quantification of DNA and relevant statistical analyses were applied to find out the impact of variation in salivary $\mathrm{pH}$ on $H$. pylori DNA detection. Thus, the $58 \%$ detection capacity (Figure 2) is comparable with similar studies in which the range of detection varies from $10 \%{ }^{30}$ to $87.5 \%{ }^{31}$ and its similar to $51 \%{ }^{16}$ It is well known that PCR has the highest efficiency in detection of $H$. pylori infection compared to routine tests such as culture ${ }^{26,32}$ and rapid urease test (RUT). In reference 13, for instance, the odd ratio $=5.51$ for $\mathrm{PCR}$ and odd ratio $=2.2$ for RUT. ${ }^{33}$ However, the inability to detect DNA in $42 \%$ of samples in this study seems to be inherent in other similar studies which can be attributed to the specific characteristics of saliva. The analyses show that increasing $\mathrm{pH}$ is statistically associated with negative PCR results (Table 3 ). Nonetheless, changes in $\mathrm{pH}$ were found to have no significant impact on the detection level (Figure 3). Such findings overall suggest the presence of mechanisms in saliva that might influence the salivary $\mathrm{pH}$ to exert anti-bacterial effects. Therefore, it is important to notice that despite the ability of $H$. pylori to tolerate the extremely acidic environment of stomach.34 The bacteria face a relatively restricted growth in saliva, which is reasonably in agreement with the findings of this study. One conceivable reason can be the colonization of various microorganisms, particularly the fast-growing bacterial species in the oral cavity. ${ }^{19}$ This can competitively inhibit the growth or often ends in entering $H$. pylori into a viable but not culturable (VBNC) state that limits the spread of $H$. pylori into the saliva. ${ }^{35}$ The diversity in nitrite concentration of human saliva, which varies depending on dietary intake from 0.05 to $1.0 \mathrm{mmol} / \mathrm{L}^{17}$ can be another reason for such discrepancy. Nitric oxide that has been recognized for its anti-bacterial function is a derivative of nitrate. In their study, Takahama and colleagues have observed that under acidic conditions, nitrate is protonated to nitrous acid, which can later be transformed into nitric oxide via reduction and self-decomposition. Thus, decreasing the $\mathrm{pH}$ of saliva increases the formation of nitric oxide depending on the nitrate level of saliva. Consequently, alteration in nitrate 
levels in saliva could potentially change the survival rate of $H$. pylori and, in the meantime, changes the $\mathrm{pH}$ of saliva. ${ }^{32}$ Taking into account the mentioned strategies and mechanisms that could possibly explain such a pattern of salivary $\mathrm{pH}$ on the detection of $H$. pylori DNA, the precise means upon which this effect can be explained has yet not been fully elucidated.

\section{Conclusion}

One of the most robust techniques to detect $H$. pylori in the saliva is Real-time PCR, which has been used in this study to investigate the association of salivary $\mathrm{pH}$ to bacterial DNA detection capacity. In this regard, $\mathrm{pH}$ of 5.5 to 7.5 was found to be more associated with the detection ability by PCR. However, the quantification of DNA showed no correlation between the increasing DNA quantities with the variation of $\mathrm{pH}$ within this range. Hence, the authors of this study recommend further studies on the link between salivary $\mathrm{pH}$ and $H$. pylori DNA detection with regard to a more detailed investigation of factors that can influence the presence of bacteria in saliva.

\section{Competing interests}

The authors declare no competing interests.

\section{References}

1. Waskito LA, Salama NR, Yamaoka $Y$. Pathogenesis of Helicobacter pylori infection. Helicobacter 2018; 23(S1):e12516.

2. Suzuki $N$, Yoneda $M$, Naito $T$, Iwamoto $T$, Masuo Y, Yamada K, et al. Detection of Helicobacter pylori DNA in the saliva of patients complaining of halitosis. J Med Microbiol 2008; 57(12):1553-9.

3. Ji R, Li YQ, Gu XM, Yu T, Zuo XL, Zhou CJ. Confocal laser endomicroscopy for diagnosis of Helicobacter pylori infection: A prospective study. J Gastroenterol Hepatol 2010; 25(4):700-5.

4. Yagi K, Saka A, Nozawa $Y$, Nakamura A. Prediction of Helicobacter pylori Status by Conventional Endoscopy, Narrow-Band Imaging Magnifying Endoscopy in Stomach after Endoscopic Resection of Gastric Cancer. Helicobacter 2014; 19(2):111-5.

5. Axon A. Helicobacter pylori and public health. Helicobacter 2014; 19:68-73.
6. Kignel S, de Almeida Pina F, André EA, Alves Mayer MP, Birman EG. Occurrence of Helicobacter pylori in dental plaque and saliva of dyspeptic patients. Oral Dis 2005; 11(1):17-21.

7. Morales-Espinosa R, Fernandez-Presas A, Gonzalez-Valencia G, Flores-Hernandez S, Delgado-Sapien G, Mendez-Sanchez JL, et al. Helicobacter pylori in the oral cavity is associated with gastroesophageal disease. Oral Microbiol Immunol 2009; 24(6):464-8.

8. Miyabayashi H, Furihata K, Shimizu T, Ueno I, Akamatsu T. Influence of oral Helicobacter pylori on the success of eradication therapy against gastric Helicobacter pylori. Helicobacter 2000; 5(1):30-7.

9. Rathbone M, Rathbone B. Helicobacter pylori and gastric cancer. In: Inflammation and Gastrointestinal Cancers Springer; 2011. P. 8397.

10. Namiot Z, Namiot DB, Kemona A, Stasiewicz J. Effect of anti-bacterial therapy and salivary secretion on the efficacy of Helicobacter pylori eradication in duodenal ulcer patients. Oral Surgery, Oral Med Oral Pathol Oral Radiol Endodontology 2004; 97(6):714-7.

11. Czesnikiewicz-Guzik M, Loster B, Bielanski W, Guzik TJ, Konturek PC, Zapala J, et al. Implications of oral Helicobacter pylori for the outcome of its gastric eradication therapy. J Clin Gastroenterol 2007; 41(2):145-51.

12. Namiot DB, Namiot Z, Kemona A, Bucki R, Gotębiewska M. Oral health status and oral hygiene practices of patients with peptic ulcer and how these affect Helicobacter pylori eradication from the stomach. Helicobacter 2007; 12(1):63-7.

13. Helmerhorst EJ. Protective functions of saliva. Saliva oral Heal 4th ed London Stephen Hancocks Ltd 2012:115-34.

14. Pink R, Simek J, Vondrakova J, Faber E, Michl P, Pazdera J, et al. Saliva as a diagnostic medium. Biomed Pap Med Fac Palacky Univ Olomouc 2009; 153(2).

15. Garza-González E, Perez-Perez GI, MaldonadoGarza HJ, Bosques-Padilla FJ. A review of Helicobacter pylori diagnosis, treatment, and methods to detect eradication. World $\mathrm{J}$ Gastroenterol WJG 2014; 20(6):1438.

16. Momtaz H, Souod N, Dabiri H, Sarshar M. Study of Helicobacter pylori genotype status in saliva, dental plaques, stool and gastric biopsy samples. World J Gastroenterol WJG 2012; 18(17):21-5.

17. Rimbara E, Sasatsu M, Graham DY. PCR detection of Helicobacter pylori in clinical samples. In: PCR Detection of Microbial Pathogens. Springer; 2013. P. 279-87.

18. Czarkowski M. Helsinki Declaration--next version. 2014.

19. Cellini L, Grande R, Artese L, Marzio L. Detection of Helicobacter pylori in saliva and 
20. Rao X, Huang X, Zhou Z, Lin X. An improvement of the2-delta delta CT) method for quantitative real-time polymerase chain reaction data analysis. Biostat Bioinforma Biomath 2013; 3(3):71-85.

21. Atherton JC, Blaser MJ. Coadaptation of Helicobacter pylori and humans: Ancient history, modern implications. J Clin Invest 2009; 119(9):2475-87.

22. Medina ML, Medina MG, Martín GT, Picón SO, Bancalari A, Merino LA. Molecular detection of Helicobacter pylori in oral samples from patients suffering digestive pathologies. Med Oral Patol Oral Cir Bucal 2010; 15(1):e38-42.

23. Huang JY, Sweeney EG, Guillemin K, Amieva MR. Multiple acid sensors control Helicobacter pylori colonization of the stomach. PLoS Pathog 2017; 13(1):e1006118.

24. Souto R, Colombo APV. Detection of Helicobacter pylori by polymerase chain reaction in the subgingival biofilm and saliva of non-dyspeptic periodontal patients. J Periodontol 2008; 79(1):97-103.

25. Haukioja A, Ihalin R, Loimaranta V, Lenander M, Tenovuo J. Sensitivity of Helicobacter pylori to an innate defence mechanism, the lactoperoxidase system, in buffer and in human whole saliva. J Med Microbiol 2004; 53(9):855-60.

26. Agüloğlu S, Turhanoğlu M, Eskimez S, Tacir I. Detection of Helicobacter pylori colonization in human dental plaques and saliva of patients with chronic gastritis. Biotechnol Biotechnol Equip 2006; 20(2):173-8.

27. Gao J, Li Y, Wang Q, Qi C, Zhu S. Correlation between distribution of Helicobacter pylori in oral cavity and chronic stomach conditions. J Huazhong Univ Sci Technol Medical Sci 2011; 31(3):409-12.

28. Bürgers $R$, Schneider-Brachert $W$, Reischl $U$, Behr A, Hiller KA, Lehn N, et al. Helicobacter pylori in human oral cavity and stomach. Eur $\mathrm{J}$ Oral Sci 2008; 116(4):297-304.

29. Wang XM, Yee KC, Hazeki-Taylor N, Li J, Fu HY, Huang ML, et al. Oral Helicobacter pylori, its relationship to successful eradication of gastric $\mathrm{H}$. pylori and saliva culture confirmation. J Physiol Pharmacol 2014; 65(4):559-66.

30. Gebara ECE, Pannuti C, Faria CM, Chehter L, Mayer MPA, Lima L. Prevalence of Helicobacter pylori detected by polymerase chain reaction in the oral cavity of periodontitis patients. Oral Microbiol Immunol 2004; 19(4):277-80.

31. Tiwari SK, Khan AA, Ahmed KS, Ahmed I, Kauser F, Hussain MA, et al. Rapid diagnosis of Helicobacter pylori infection in dyspeptic patients using salivary secretion: a non-invasive approach. Singapore Med J 2005; 46(5):224.

32. Takahama U, Oniki T, Hirota S. Oxidation of quercetin by salivary components. Quercetindependent reduction of salivary nitrite under acidic conditions producing nitric oxide. J Agric
Food Chem 2002. doi:10.1021/jf011697q

33. Zou Q, Li R. Helicobacter pylori in the oral cavity and gastric mucosa: a meta-analysis. J Oral Pathol Med 2011; 40(4):317-24.

34. Stingl K, Altendorf K, Bakker EP. Acid survival of Helicobacter pylori: how does urease activity trigger cytoplasmic pH homeostasis? Trends Microbiol 2002; 10(2):70-4.

35. Andersen LP, Rasmussen L. Helicobacter pylori - Coccoid forms and biofilm formation. FEMS Immunol Med Microbiol 2009; 56(2):112-5. 